\title{
Man of the century
}

To the Editor,

In June 1997, the journal devoted an entire issue to assisted suicide and euthanasia. In the November-December 1999 issue, Drs Rodriguez and Gorovitz ${ }^{1}$ imply that guns have no acceptable uses, so the civilian population should be disarmed. Drs Caplan, McGee, and Magnus" ask, "What is immoral about eugenics?" and conclude that the pursuit of "perfection" is permissible if coercion is absent. How to guarantee its absence is not stated. In short, the authors, and presumably the editors, believe it is both ethical and safe to construct a society in which the elite are free to pursue their notions of perfectionand, by extension, their desires on what to do with imperfection—on a helpless populace. I would be fascinated to learn my uncle's opinion of these developments, but I cannot do so; he died in the Lodz Ghetto during the Holocaust.

The mere fact that the Nazis did something does not mean we must avoid it. Hitler detested smoking, was a vegetarian, and drank little alcohol; this does not mean I should smoke a pack of cigarettes daily, eat red meat at every meal, and drink myself into a stupor. But if what the Nazis did was integral to their murderous program, surely we should be reluctant to do something similar. That the ideas of euthanasia and eugenics, plus a disarmed populace, do not evoke anxiety in many physicians and scientists is a source of profound disappointment. Recently Time chose Albert Einstein as person of the century. With due respect for the gentle genius, Time was wrong. The person with the most lasting influence was clearly Adolf Hitler.

David C Stolinsky

1200 N State St, Room 10-420

Los Angeles, CA 90033

stolinsky@prodigy.net

Competing interests None declared

References

1 Rodriguez MA, Gorovitz E. The politics and prevention of gun violence: physicians are morally obligated to help prevent gun trauma. West J Med 1999;171:296-297.

2 Caplan AL, McGee G, Magnus D. What is immoral about eugenics? West J Med 1999;171:335-337. 